Western North American Naturalist 67(4), (C) 2007, pp. 572-586

\title{
POPULATION DENSITY, BIOMASS, AND AGE-CLASS STRUCTURE OF THE INVASIVE CLAM CORBICULA FLUMINEA IN RIVERS OF THE LOWER SAN JOAQUIN RIVER WATERSHED, CALIFORNIA
}

\author{
Larry R. Brown ${ }^{1}$, Janet K. Thompson², Karen Higgins ${ }^{2,3}$, and Lisa V. Lucas ${ }^{2}$
}

\begin{abstract}
Corbicula fluminea is well known as an invasive filter-feeding freshwater bivalve with a variety of effects on ecosystem processes. However, C. fluminea has been relatively unstudied in the rivers of the western United States. In June 2003, we sampled C. fluminea at 16 sites in the San Joaquin River watershed of California, which was invaded by C. fluminea in the 1940s. Corbicula fluminea was common in 2 tributaries to the San Joaquin River, reaching densities of 200 clams $\cdot \mathrm{m}^{-2}$, but was rare in the San Joaquin River. Biomass followed a similar pattern. Clams of the same age were shorter in the San Joaquin River than in the tributaries. Distribution of clams was different in the 2 tributaries, but the causes of the difference are unknown. The low density and biomass of clams in the San Joaquin River was likely due to stressful habitat or to water quality, because food was abundant. The success of $C$. fluminea invasions and subsequent effects on trophic processes likely depends on multiple factors. As $C$. fluminea continues to expand its range around the world, questions regarding invasion success and effects on ecosystems will become important in a wide array of environmental settings.
\end{abstract}

Key words: Corbicula fluminea, alien species, invasive species, San Joaquin River, Merced River, Tuolumne River.

The invasive bivalve Corbicula fluminea can have a variety of effects on aquatic ecosystems. Understanding these effects remains important as C. fluminea continues to expand its range, most recently in South America and Europe (McMahon 1999). Initial interest in $C$. fluminea in California (Ingram 1959, Eng 1979) and throughout the United States centered on its potential as a pest in water supply infrastructure (McMahon 1983). There were few studies of the ecosystem-level effects of the $C$. fluminea invasion until the 1980s, when filtration by $C$. fluminea was noted to be limiting pelagic food sources (Cohen et al. 1984, Lauritsen 1986, McMahon and Williams 1986). In the 1990s, the presence of C. fluminea was associated with changes in zooplankton community structure (Beaver et al. 1991). Corbicula fluminea has also been associated with other effects on invaded ecosystems, including alterations in cycling of organic matter in the substrate (Hakenkamp and Palmer 1999), changes in nutrient cycling (Lauritsen and Mozely 1989, Beaver et al. 1991), changes in composition of the benthic community (Hakenkamp et al. 2001), and system-level ecological change (Phelps 1994). Recent work in the Sacra-
mento-San Joaquin Delta indicates that $C$. fluminea may be suppressing primary production (Lucas et al. 2002), and thus pelagic secondary production, as Potamocorbula amurensis does in the brackish parts of the estuary (Kimmerer 2002). Most of the work on C. fluminea populations in the United States has occurred in eastern streams, where it is widely established (U.S. Geological Survey 2005). There have been no published studies of the ecological effects of $C$. fluminea in the nontidal streams and rivers of the western United States, even though the species is established in many of the major river basins (U.S. Geological Survey 2005).

Given previous work in other geographic areas, it seems likely that invasion of C. fluminea into western rivers was associated with changes in ecosystem processes, particularly trophic pathways. Understanding the trophic linkages from phytoplankton, periphyton, and particulate organic matter to invertebrates, and ultimately to fish, is important for the effective management of ecosystems. In California, $C$. fluminea invaded the delta and its tributary rivers, including the San Joaquin River, circa 1945 (Ingram 1959). Thus, the San Joaquin River drainage provides an opportunity to study

\footnotetext{
${ }^{1}$ U.S. Geological Survey, Placer Hall, 6000 J Street, Sacramento, CA 95819-6129. E-mail: lrbrown@usgs.gov

${ }^{2}$ U.S. Geological Survey, 345 Middlefield Road, Mailstop 496, Menlo Park, CA 94025.

3Present address: North Carolina Department of Environment and Natural Resources, Division of Water Quality, 1617 Mail Service Center, Raleigh, NC 27699-1617.
} 


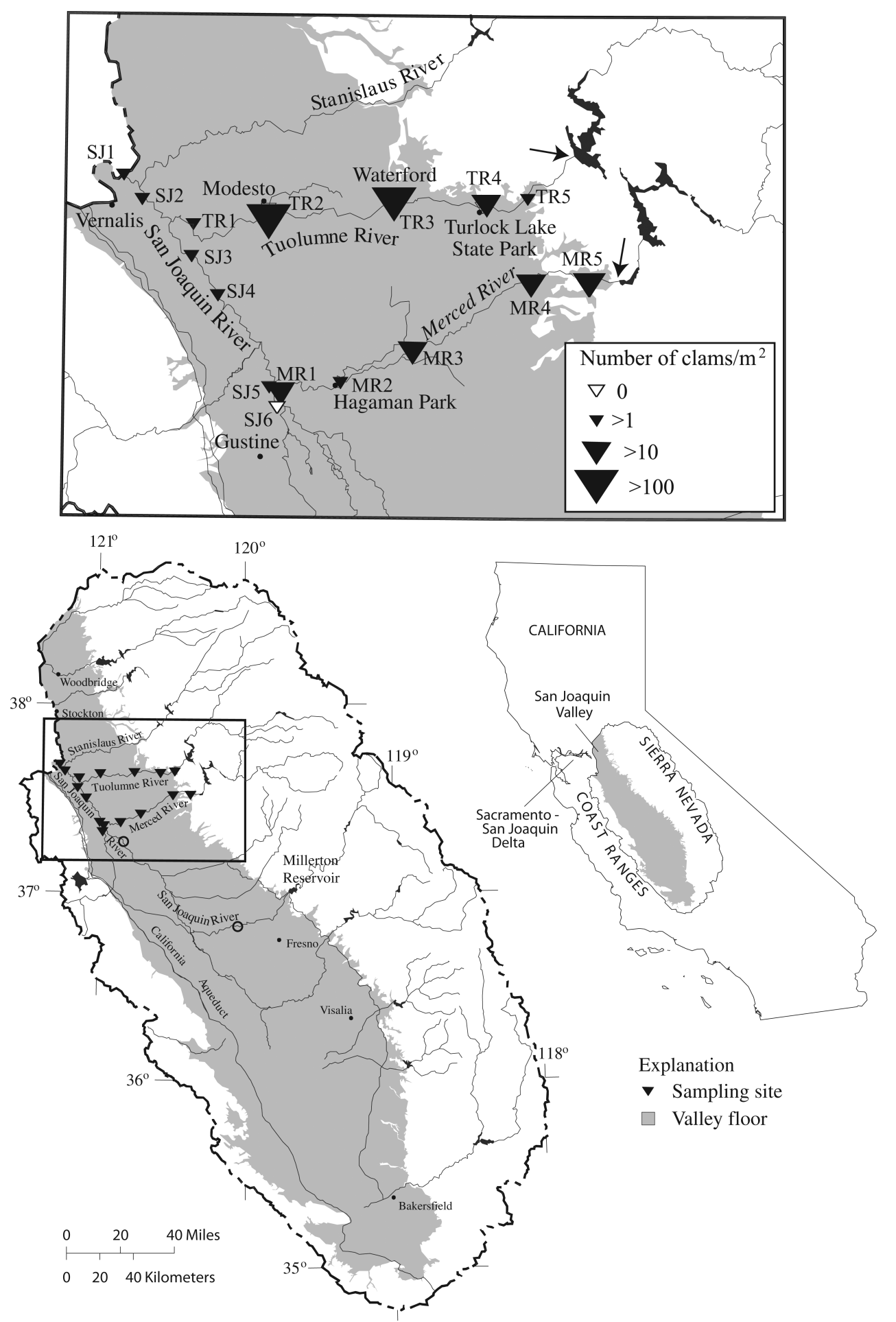

Fig. 1. Locations of 16 sites sampled for Corbicula fluminea in the lower San Joaquin River drainage, California. Arrows indicate dams delimiting the top of the study reaches in the tributary rivers. The 2 open circles on the lower figure mark the approximate upper and lower ends of the reach of the San Joaquin River without perennial flow. 
a well-established population of $C$. fluminea and evaluate the potential effect of this invasive bivalve on stream ecosystems. Accordingly, we examined the distribution, density, biomass, and age-class structure of $C$. fluminea in the lower San Joaquin River upstream of tidal influence and in 2 of its major tributaries, namely, the Tuolumne and Merced rivers (Fig. 1). We also tested for relationships between measures of clam abundance and selected habitat variables and water quality variables in an effort to understand the environmental factors associated with patterns of clam abundance.

\section{Study Area}

The San Joaquin, Merced, and Tuolumne rivers drain the San Joaquin Valley of California (Fig. 1). The upper portions of the watersheds consist primarily of forested lands in the foothills and upper elevations of the Sierra Nevada. Agriculture, primarily irrigated farmland, dominates the lower valley floor portions of the watersheds; however, urban areas are rapidly expanding. All 3 rivers are dammed near the transition from the foothills of the Sierra Nevada to the valley floor (Fig. 1). The stored water is diverted into canal systems or released into the downstream channel to supply downstream uses and provide flood control. These operations have substantially altered natural hydrologic regimes and geomorphic processes (Kahrl et al. 1978, Mount 1995). Irrigation return flows and the intensive use of pesticides and fertilizers have adversely affected water quality on the valley floor (Kuivila and Foe 1995, Brown 1997a, 1997b, Domagalski et al. 1997, Kratzer and Shelton 1999).

This study was conducted in the downstream reaches of the tributary rivers below the dams and in the lower San Joaquin River beginning just upstream of the Merced River (Fig. 1). Flow releases from Millerton Reservoir, which is on the San Joaquin River, are insufficient to maintain surface flow within a long reach of the river from below the dam to just above the confluence of the Merced River (Fig. 1; Brown 1997a). Upstream of the Merced River, the flow in the San Joaquin River consists mainly of agricultural return flow. During our study, river flows were steady or slowly declining except at the farthest downstream San Joaquin River site (SJ1). Flows at this site were variable, due to water management ac- tivites on the Stanislaus River, but never approached flood levels.

\section{Methods}

Data Collection

Corbicula fluminea was collected in June 2003 from 16 sites in the lower San Joaquin, Tuolumne, and Merced rivers (Fig. 1). Sites on the mainstem San Joaquin River were located to bracket the confluences of tributary rivers. Sites on the Tuolumne and Merced rivers represented the variety of habitats below the foothill dams. Specifically, the 2 upstream sites in both tributaries were located in a region of higher gradient and coarse substrate with welldeveloped riffle-pool habitat. The 2 downstream sites were located in a region of lower gradient and fine substrate dominated by run habitat. The middle site represented a transition zone. All of the mainstem San Joaquin River sites were located in a region of lower gradient and fine substrate dominated by run habitat.

At each sampling site, C. fluminea densities were determined within a reach of stream with a linear extent corresponding to approximately 20 times the mean channel width. A stream reach of this length adequately captures stream habitat heterogeneity (Fitzpatrick et al. 1998). Eleven evenly spaced transects, each oriented perpendicular to stream flow, were sampled within each reach. At each transect, C. fluminea was collected at 5 points: $25 \%, 50 \%$, and $75 \%$ of stream width and 1 point within $2 \mathrm{~m}$ of the stream edge at each bank. At each point, a clam sample was collected from a $0.165-\mathrm{m}^{2}$ area in front of a rectangular kick net with a net bag approximately $30 \mathrm{~cm}$ deep with 2 -mm mesh. When present, large rocks were removed from the area in front of the net, and then sand and gravel were kicked toward the net opening. This action disturbed the substrate to a depth of $10 \mathrm{~cm}$. In clear water we occasionally noted clams remaining in the sample area after kicking, so our estimates represent minimum estimates of the numbers present. To prevent biasing our samples compared to turbid water samples, we did not collect the remaining visible clams. When water depth was too great to use the kick net, we used a pole-mounted Eckman dredge $\left(0.052 \mathrm{~m}^{2}\right)$. The dredge samples were sieved through a 2 -mm sieve. Our methods were not adequate to collect the smallest clams present ( $<2 \mathrm{~mm} \mathrm{SL}$, maximum shell length); 
however, this bias was present for all samples and does not affect comparisons between sites.

At each sampling point on a transect, stream depth was measured with a calibrated wading rod. Mean water column velocity was determined with a Marsh-McBirney electronic flow meter. The dominant substrate at the sample point was categorized visually (see Table 1 for categories). We were unable to sample locations deeper than our pole $(3 \mathrm{~m})$ or locations with substrate that could not be moved by hand (i.e., boulders). All $C$. fluminea individuals collected at a sampling site were composited into a single sample. Subsamples, which represented the size range of $C$. fluminea collected, were frozen to determine biomass. Any remaining clams were preserved in $10 \%$ buffered formalin. Preserved clams were transferred to $70 \%$ ethyl alcohol after 7-10 days. Water temperature was measured at the beginning and end of sampling activities at each site.

All 55 transect points were successfully sampled at only 3 of 16 sites (Table 1). At 2 sites in the Merced River (MR3 and MR5) and 1 site in the Tuolumne River (TR3), entire transects were not sampled $(5,3$, and 1 transect, respectively) because of the presence of deep pools $(>2 \mathrm{~m})$ with large substrate materials (large cobbles and small boulders) that were not amenable to sampling with the Eckman dredge. The remaining missing points represent isolated transect points that could not be sampled for reasons of depth or substrate.

In the laboratory, maximum shell lengths (SL) of all collected C. fluminea were measured to the nearest $0.1 \mathrm{~mm}$ using Vernier calipers. Corbicula fluminea in the frozen subsample were sorted into 1-mm SL size groups for each site. The clams within each 1-mm size group at each site were then placed into individual pans. At sites where clams were abundant, 1-mm size groups from each site were split into 2 pans. All pans were then placed in a $60^{\circ} \mathrm{C}$ oven (for $\geq 7$ days), weighed (dry mass, $\mathrm{DM}$ ), combusted at $500^{\circ} \mathrm{C}$, and reweighed (ash mass, AM; Crisp 1971). The resulting ash-free dry mass (AFDM) of the clams in each 1-mm size group was determined by difference $(\mathrm{AFDM}=\mathrm{DM}-\mathrm{AM})$. Data from all sites on a river were combined for determination of a river-specific regression equation. These equations were then used to estimate biomass of individual C. fluminea in the preserved samples.
Age structure of the $C$. fluminea population at each site was analyzed using Mix 3.1.3 for Macintosh (Macdonald and Green 1988). This program discerns mixtures of distributions within size frequency distributions by the method of maximum likelihood. The component densities can be normal, lognormal, gamma, or Weibull distributions. The parameters were not constrained for these analyses. Age structure was analyzed assuming 2 reproductive periods per year for C. fluminea in this system (Foe and Knight 1985). We tested for differences among rivers in $\log _{10}$-transformed mean SL at each age (as calculated by Mix) using ANOVA followed by Tukey pairwise comparisons.

Specific conductance, chlorophyll- $a$ (chl- $a$ ), and suspended particulate matter (SPM) were determined at 4 sites on 1 day in each river during a 2 nd sampling period that was separated from the $C$. fluminea collections by $\leq 21$ days. Flows were steady or declining slowly between sampling periods, and thus we assumed that redistribution of clams between benthic and water column sampling periods was minimal. Water samples (1 L) were collected as midstream subsurface grabs, which Kratzer et al. (2004) found to be comparable to width- and depth-integrated samples in the lower San Joaquin River (median relative percentage difference $=12 \%, n=8)$. Specific conductance was measured with an electronic meter. Chlorophyll- $a$ was analyzed according to standard methods (Parsons et al. 1984), as was SPM (Hager 1994).

To supplement our single-event environmental sampling we obtained longer-term data from other sources. Such data were not available for every site sampled, but the data do allow comparisons between rivers. We obtained flow data for the 20 years preceding our sampling from USGS gages located at the upstream end of our study reaches in the Merced and Tuolumne rivers and at sites SJ1 and SJ5 on the San Joaquin River. We obtained unpublished data for water temperature, specific conductance, $\mathrm{pH}$, chl- $a$, dissolved calcium concentration, and SPM from Dr. Randy Dahlgren (University of California, Davis). We used data from twice monthly sampling at sites MR1, TR1, SJ1, SJ4, and at a location approximately $4 \mathrm{~km}$ upstream of SJ2. Four additional sampling events during the time period were also included. Methods and sampling 


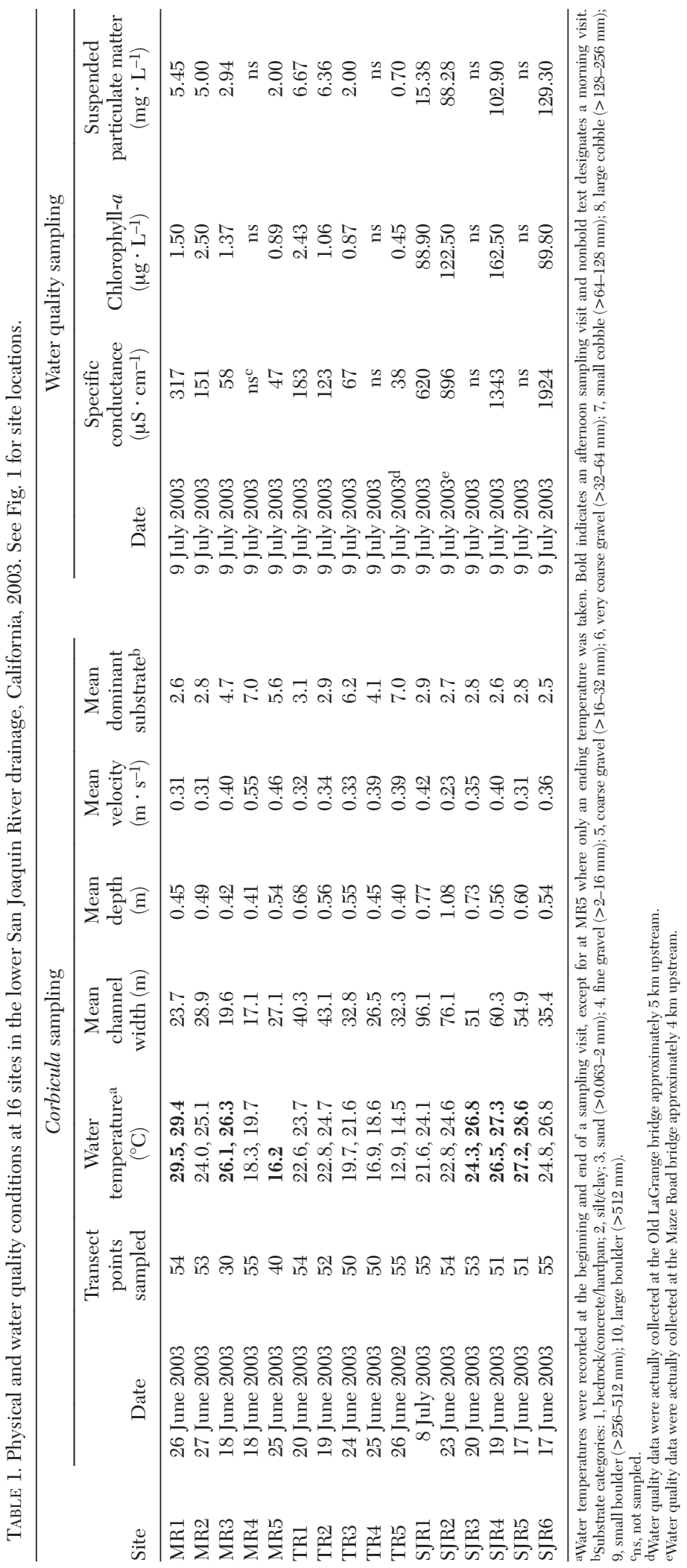


TABLE 2. Mean $( \pm s)$ and range (in parentheses) for selected water quality variables from twice monthly sampling from July 2001 through June $2003(n=52,4$ additional sampling events were also included) at 5 sites in the lower San Joaquin River drainage, California (R. Dahlgren, University of California, Davis, unpublished data).

\begin{tabular}{lcccccc}
\hline Site & $\begin{array}{c}\text { Water } \\
\text { temperature } \\
\left({ }^{\circ} \mathrm{C}\right)\end{array}$ & $\begin{array}{c}\text { Specific } \\
\text { conductance } \\
\left(\mu \mathrm{S} \cdot \mathrm{cm}^{-1}\right)\end{array}$ & $\mathrm{pH}$ & $\begin{array}{c}\text { Dissolved } \\
\text { calcium } \\
\left(\mathrm{mg} \cdot \mathrm{L}^{-1}\right)\end{array}$ & $\begin{array}{c}\text { Shlorophyll- } a \\
\left(\mu \mathrm{g} \cdot \mathrm{L}^{-1}\right)\end{array}$ & $\begin{array}{c}\text { Suspended } \\
\text { particulate matter } \\
\left(\mathrm{mg} \cdot \mathrm{L}^{-1}\right)\end{array}$ \\
\hline MR1 & $18.0 \pm 5.4$ & $180 \pm 88$ & $7.8 \pm 0.2$ & $17 \pm 7$ & $3.07 \pm 1.91$ & $11.89 \pm 6.53$ \\
TR1 & $(8.0-27.8)$ & $(43-344)$ & $(7.3-8.4)$ & $(5-30)$ & $(0.24-7.66)$ & $(3.70-41.71)$ \\
& $17.6 \pm 5.2$ & $212 \pm 60$ & $7.9 \pm 0.2$ & $20 \pm 6$ & $3.62 \pm 1.88$ & $10.70 \pm 5.82$ \\
SJ1 & $(8.5-27.7)$ & $(55-303)$ & $(7.4-8.4)$ & $(5-28)$ & $(0.50-9.72)$ & $(2.80-28.19)$ \\
& $17.2 \pm 5.1$ & $689 \pm 195$ & $8.0 \pm 0.2$ & $45 \pm 13$ & $27.10 \pm 27.01$ & $47.19 \pm 14.52$ \\
SJ2 & $(7.9-28.1)$ & $(305-1027)$ & $(7.6-8.5)$ & $(20-71)$ & $(2.00-105.18)$ & $(25.50-81.25)$ \\
& $17.7 \pm 5.2$ & $889 \pm 236$ & $8.0 \pm 0.2$ & $54 \pm 13$ & $33.56 \pm 35.37$ & $64.22 \pm 43.50$ \\
SJ4 & $(8.6-26.7)$ & $(342-1302)$ & $(7.6-8.6)$ & $(22-75)$ & $(2.16-133.10)$ & $(16.32-209.20)$ \\
& $18.2 \pm 5.4$ & $1181 \pm 261$ & $8.0 \pm 0.2$ & $73 \pm 18$ & $31.06 \pm 33.03$ & $58.21 \pm 23.31$ \\
& $(8.5-27.1)$ & $(424-1607)$ & $(7.6-8.5)$ & $(27-116)$ & $(1.56-125.74)$ & $(18.00-112.00)$ \\
\hline
\end{tabular}

procedures are documented in Kratzer et al. (2004). Our sampling-event measurements represent conditions during a warm, highly productive period when clams are expected to be in good condition, and the longer-term data place the sampling-event data in the multiyear context important in determining population structure.

\section{Data Analysis}

We compared SL, density (total number per unit area sampled), and biomass (total AFDM per unit area sampled) of clams in each river using ANOVA followed by Tukey pairwise comparisons. The data were $\log _{10}$-transformed to improve normality and to reduce heteroscedasticity. We related density and biomass to environmental conditions using Spearman rank correlations. Measures of environmental conditions included (1) chl- $a$ as a measure of food availability; (2) mean depth, mean velocity, mean dominant substrate size, and water temperature as measures of habitat condition; and (3) specific conductance and SPM as measures of water quality. Values for SPM actually depend on suspended material of both organic (e.g., suspended algae) and inorganic (e.g., suspended sediment) origin, so this measure also reflects food availability.

We compared AFDM adjusted for SL (a measure of condition) of $C$. fluminea using analysis of covariance (ANCOVA). For the pairwise comparisons of rivers, we used the Bonferroni correction to adjust the significance level for multiple pairwise tests. Both SL and AFDM data were $\log _{10}$-transformed for analysis.
Results

Habitat and water quality conditions varied widely between rivers and between sites on the same river (Table 1). Compared with the tributaries, the San Joaquin River was wider and deeper with less heterogeneity in temperature and substrate size between sites. Water temperatures were always warm, with all measurements exceeding $20^{\circ} \mathrm{C}$. The substrate was dominated by fine particles (sand or smaller) at all sites. Specific conductance and SPM declined from upstream to downstream in the San Joaquin River, whereas chl- $a$ was highest at the intermediate sites (SJR2 and SJR4). Chlorophyll- $a$ was approximately 2 orders of magnitude higher in the San Joaquin River than in the tributaries. At some sites, specific conductance and SPM were an order of magnitude higher in the San Joaquin River than in the tributary rivers.

In the Merced and Tuolumne rivers, water temperature, specific conductance, chl- $a$, and SPM tended to increase from upstream sites to downstream sites (Table 1). Mean substrate size exhibited an opposite trend, with upstream sites having larger substrate (gravel or larger) and downstream sites dominated by mixtures of fine substrates (sand or smaller).

Flow in all 3 rivers was low to moderate during the 3 years preceding our sampling (Fig. 2 ). The California Department of Water Resources considered 2001 and 2002 to be dry and 2003 to be below normal based on a scale of decreasing basin runoff: wet, above normal, below normal, dry, or critically dry (http://cdec .water.ca.gov/cgi-progs/iodir/wsihist). The most 


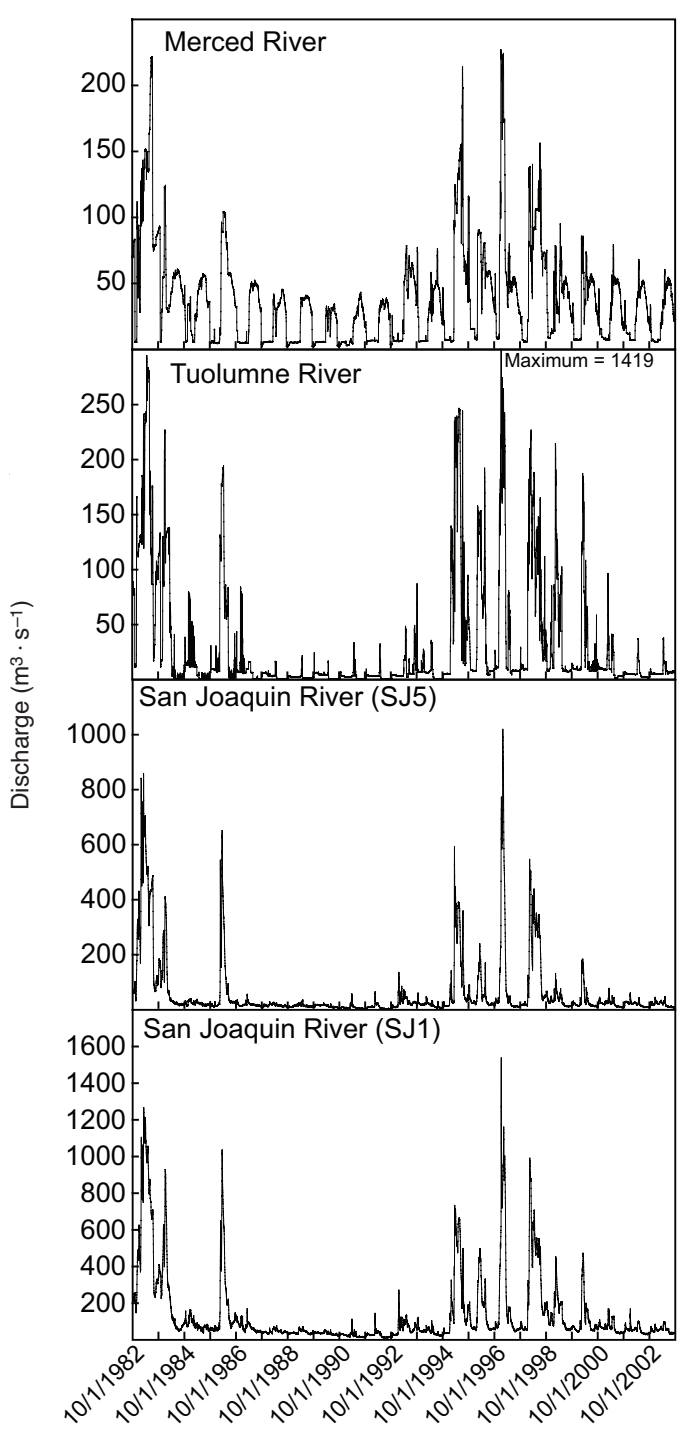

Fig. 2. Discharge records for the 20 water years (a water year is from 1 October to 31 September of the next year) preceding clam sampling from stream gages located near the top of the sampling reach in the Merced and Tuolumne rivers and at sites SJ1 and SJ5 on the San Joaquin River. See Fig. 1 for site locations.

recent major flood occurred in late 1996 to early 1997 (Fig. 2). The long-term water quality data (Table 2) showed patterns and magnitudes similar to our sampling-event measurements (Table 1). Specific conductance was higher in the San Joaquin River than in the tributaries, with little overlap in the range of values (Table 2). Mean dissolved calcium was approximately 3 times higher in the San Joaquin River than in the tributaries. Mean chl- $a$ was about 10 times higher in the San Joaquin River than in the tributaries. Suspended particulate matter was 5 to 6 times higher in the San Joaquin River than in the tributaries. Values for $\mathrm{pH}$ were similar at all sites and ranged from 7.3 to 8.6. Temperature was also similar at all sites and ranged from $7.9^{\circ}$ to $27.8^{\circ} \mathrm{C}$; however, these samples were taken at the farthest downstream and warmest sites on the tributaries.

There were statistically significant differences in SL among rivers (ANOVA, $F_{2,4330}=$ 156.1, $P<0.001)$. The rivers were all different from each other (all $P<0.001$ ). Mean SL of clams was smallest in the San Joaquin River $(\bar{x}=6.7 \mathrm{~mm}, 95 \%$ C.I. $6.1-7.5 \mathrm{~mm}, n=66)$, intermediate in the Merced River $(\bar{x}=13.3$ $\mathrm{mm}, 95 \%$ C.I. $12.9-13.8 \mathrm{~mm}, n=712$ ), and largest in the Tuolumne River $(\bar{x}=14.3 \mathrm{~mm}$, $95 \%$ C.I. $14.1-14.4 \mathrm{~mm}, n=3555)$. The difference between the Merced and Tuolumne rivers was only $1 \mathrm{~mm}$, but was statistically significant because of high statistical power resulting from the large sample sizes. Patterns in SL within each river were different (Fig. 3). All clams from the San Joaquin River were small; all but 1 measured < $14 \mathrm{~mm}$ SL. In the Tuolumne River, the upstream site had no small individuals (Fig. 3). The downstream site had the largest individuals but also the smallest median size. The C. fluminea populations at the lower Merced River sites (MR1-3) had relatively uniform mixtures of small and large individuals, and median sizes were larger than those in the Tuolumne River (Fig. 3). The upstream Merced River sites (MR4 and MR5) had fewer large clams and smaller median sizes (11-13 mm SL) than the downstream sites.

There were significant statistical differences in density (ANOVA: $F_{2,13}=7.2, P<0.01$ ) and biomass (ANOVA: $F_{2,13}=7.7, P<0.01$ ) among the rivers. The Tuolumne River had significantly higher densities than the San Joaquin River $(P<0.01$, Table 3$)$. The difference in densities between the Merced River and the San Joaquin River was nearly significant $(P=$ 0.051), with the Merced River having higher densities. The densities in the Merced and Tuolumne rivers were not different $(P>0.05)$. The pattern for biomass was similar, with biomass highest in the Tuolumne River, intermediate in the Merced River, and lowest in the San Joaquin River (Table 3). The highest 


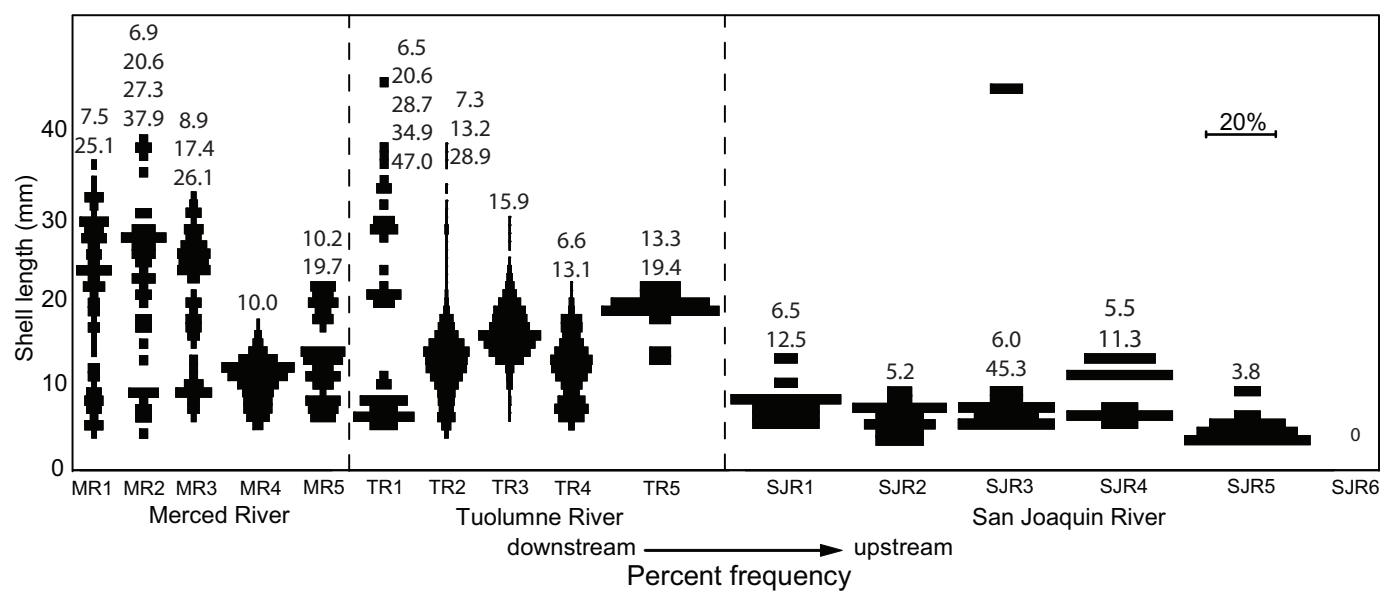

Fig. 3. Frequency histograms of shell lengths $(\mathrm{mm})$ of Corbicula fluminea at 16 sites in the lower San Joaquin River drainage, California. Mean length $(\mathrm{mm})$ for each age class is given for each site from youngest (top) to oldest (bottom) clams.

TABLE 3. Total area sampled, density, and biomass of Corbicula fluminea at 16 sites in the lower San Joaquin River drainage, California, 2003.

\begin{tabular}{lcrc}
\hline Site & $\begin{array}{c}\text { Area } \\
\text { sampled }\left(\mathrm{m}^{2}\right)\end{array}$ & $\begin{array}{c}\text { Density } \\
\left(\text { clams } \cdot \mathrm{m}^{-2}\right)\end{array}$ & $\begin{array}{c}\text { Biomass } \\
\left.\text { AFDM } \cdot \mathrm{m}^{-2}\right)\end{array}$ \\
\hline MR1 & 8.92 & 12 & 3.14 \\
MR2 & 8.76 & 5 & 1.75 \\
MR3 & 4.96 & 20 & 3.09 \\
MR4 & 9.09 & 43 & 1.10 \\
MR5 & 6.61 & 11 & 1.02 \\
TR1 & 8.92 & 6 & 1.11 \\
TR2 & 8.59 & 146 & 6.29 \\
TR3 & 8.26 & 201 & 15.26 \\
TR4 & 8.26 & 69 & 2.97 \\
TR5 & 9.09 & 2 & 0.23 \\
SJR1 & 9.09 & 2 & 0.02 \\
SJR2 & 7.68 & 2 & 0.01 \\
SJR3 & 8.76 & 1 & 0.36 \\
SJR4 & 8.43 & 1 & 0.03 \\
SJR5 & 2.67 & 5 & 0.01 \\
SJR6 & 2.88 & 0 & 0 \\
\hline
\end{tabular}

biomass value in the San Joaquin River (SJ3) declined to $0.01 \mathrm{~g} \mathrm{AFDM} \cdot \mathrm{m}^{-2}$ when the single large clam collected in the San Joaquin River was omitted. For biomass, both the Merced and Tuolumne Rivers were significantly different from the San Joaquin River $(P$ $<0.05)$, but not different from each other $(P>$ $0.05)$. Within rivers, C. fluminea density and biomass were low throughout the San Joaquin River (Table 3). Lowest values within the Tuolumne River were found at the farthest upstream and farthest downstream sites (Table
TABLE 4. Spearman rank correlations of Corbicula fluminea population density $\left(\mathrm{clams} \cdot \mathrm{m}^{-2}\right.$ ), and biomass ( $\mathrm{g}$ AFDM $\cdot \mathrm{m}^{-2}$ ), with selected environmental variables in the lower San Joaquin River watershed, 2003. Sample size was 12 for specific conductance, chlorophyll- $a$ and suspended particulate matter, and 16 for the other variables. Significant correlations have an asterisk.

\begin{tabular}{lcc}
\hline & $\begin{array}{c}\text { Density } \\
\left(\text { clams } \cdot \mathrm{m}^{-2}\right)\end{array}$ & $\begin{array}{c}\text { Biomass } \\
\left(\mathrm{g} \cdot \mathrm{m}^{-2}\right)\end{array}$ \\
\hline Water temperature $(\mathrm{C})$ & -0.35 & -0.16 \\
Water depth $(\mathrm{m})$ & -0.39 & -0.41 \\
Water velocity $\left(\mathrm{m} \cdot \mathrm{s}^{-1}\right)$ & 0.02 & -0.10 \\
Mean dominant substrate & $0.58^{*}$ & 0.40 \\
Specific conductance $\left(\mu \mathrm{S} \cdot \mathrm{cm}^{-1}\right)$ & $-0.61^{*}$ & -0.56 \\
Chlorophyll- $a\left(\mu \mathrm{g} \cdot \mathrm{L}^{-1}\right)$ & $-0.68^{*}$ & $-0.64^{*}$ \\
Suspended particulate matter & $-0.61^{*}$ & $-0.60^{*}$ \\
\hline
\end{tabular}

3). Biomass in the Merced River mostly increased from upstream to downstream sites, whereas density did not show a consistent pattern.

Density had the greatest number of significant correlations and was positively correlated with mean dominant substrate and negatively correlated to specific conductance, chl- $a$, and SPM (Table 4). Biomass was negatively correlated to chl- $a$ and SPM. Examination of scatter plots suggested that the correlations might largely be attributed to the San Joaquin River sites, which had low abundances of clams and high values for specific conductance, chl- $a$, and SPM. We recalculated the correlations after excluding the San Joaquin River sites and found 
TABLE 5. Regression equations for conversion of maximum shell length (SL, mm) of Corbicula fluminea to ash-free dry mass (AFDM, g) for the Merced, Tuolumne, and San Joaquin rivers, California, 2003. Regressions for the Merced and Tuolumne rivers were calculated for the restricted size range of clams found in the San Joaquin River and for the full size range found in each river. Each data point (n) represents a mean AFDM value for 1 or more clams in the same 1$\mathrm{mm}$ size group. The total number of clams in the regression is the summation of clams from all size groups. The regressions were then used to calculate the mean and 95\% confidence interval for the AFDM of a $10 \mathrm{~mm}$ SL Corbicula fluminea.

\begin{tabular}{|c|c|c|c|c|c|c|c|}
\hline \multirow[b]{2}{*}{ Site code } & \multicolumn{5}{|c|}{$\begin{array}{c}\text { Regression equation } \\
\log (\text { AFDM })=a(\log [\text { SL }])-b\end{array}$} & \multicolumn{2}{|c|}{$\begin{array}{c}\text { Predicted AFDM } \\
\text { for a } 10 \mathrm{~mm} \text { SL clam }(\mathrm{mg})\end{array}$} \\
\hline & a & $\mathrm{b}$ & $\mathrm{n}$ & $\begin{array}{c}\text { Total } \\
\text { number of clams }\end{array}$ & $\mathrm{R}^{2}$ & Mean & $\begin{array}{l}95 \% \text { confidence } \\
\text { interval }\end{array}$ \\
\hline \multicolumn{8}{|l|}{ MR } \\
\hline SL: $4-14 \mathrm{~mm}$ & 3.61 & -5.43 & 44 & 526 & 0.96 & 15.1 & $14.2-16.0$ \\
\hline SL: $4-40 \mathrm{~mm}$ & 3.11 & -4.93 & 109 & 378 & 0.97 & 15.1 & $14.2-16.0$ \\
\hline \multicolumn{8}{|l|}{ TR } \\
\hline SL: $4-14 \mathrm{~mm}$ & 3.39 & -5.27 & 50 & 1354 & 0.99 & 13.3 & $13.0-13.6$ \\
\hline SL: $4-47 \mathrm{~mm}$ & 3.08 & -4.95 & 110 & 899 & 0.98 & 13.4 & $13.0-14.0$ \\
\hline \multicolumn{8}{|l|}{ SJR } \\
\hline SL: $3-14 \mathrm{~mm}$ & 3.50 & -5.22 & 28 & 65 & 0.97 & 19.0 & $16.9-21.0$ \\
\hline
\end{tabular}

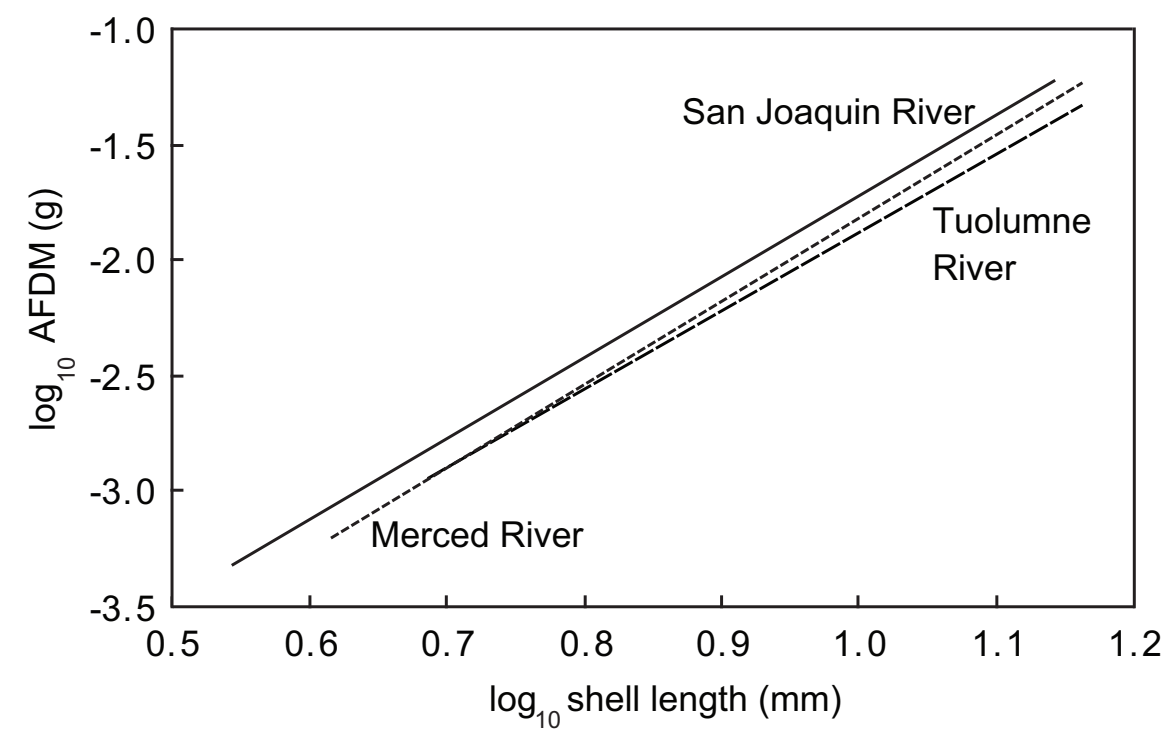

Fig. 4. Regression lines for the relationship between $\log _{10}$-transformed shell length and $\log _{10}$-transformed ash-free dry mass (AFDM) for Corbicula fluminea of $<14 \mathrm{~mm}$ shell length from the Merced, Tuolumne, and San Joaquin rivers.

no significant correlations of density or biomass with environmental variables.

Because of the disparity in SL among the rivers, we limited the Merced and Tuolumne river data to the same size range found in the San Joaquin River data (clams < $14 \mathrm{~mm} \mathrm{SL}$ and excluding the single large clam collected) when testing for differences in AFDM between rivers. ANCOVA indicated that there were significant differences among rivers $\left(F_{2,114}=\right.$ 26.1, $P<0.001$ ), and pairwise comparisons indicated that all the rivers were statistically different from one another (all $P<0.01$; Fig. 4). Although the regression slopes were not statistically different, the regression line for the Merced River appeared to converge on the line for the San Joaquin River, while the line for the Tuolumne River appeared to diverge from line for the San Joaquin River. Using the regression equations created for each river (the regressions based on all sizes for the Merced and Tuolumne rivers), we calculated 
the AFDM of a "standard" 10-mm SL clam for each river (Table 5). These numbers fell within the range found previously for $C$. fluminea in the San Joaquin Delta region (Foe and Knight 1985). Based on the $95 \%$ confidence intervals, each river was different from the others (Table 5); however, based on the regression lines (Fig. 4), the difference between the Merced and Tuolumne rivers would be less at smaller SL.

The age structure of $C$. fluminea varied within and among rivers (Fig. 3). At many sites (MR4, TR3, SJR2, and SJR5), there was only 1 age class present; however, at other sites, 2 (MR1, MR5, TR4, TR5, SJR1, SJR3, and SJR4), 3 (MR3 and TR2), 4 (MR2), or 5 (TR1) age classes were present. In general, higher numbers of age classes were found at downriver sites except on the San Joaquin River, which showed no trend.

The mean SL of clams in each age class varied among sites. An age-1 clam (assumed to be winter-spring 2003 recruits) ranged from 3.8 $\mathrm{mm} \mathrm{SL}$ in the San Joaquin River (SJR5) to 15.9 $\mathrm{mm}$ SL at the midriver site on the Tuolumne River (TR3), but an age-2 clam ranged from $11.3 \mathrm{~mm} \mathrm{SL}$ (SJR4) to $25.1 \mathrm{~mm}$ SL (MR1; Fig. $3)$.

Mean SL of age-1 clams was significantly different between rivers (ANOVA: $F_{2,12}=7.3$, $P<0.05$ ). Pairwise tests showed that mean SL of age-1 clams was larger in the Tuolumne River than in the San Joaquin River, but was not different from mean SL of age-1 clams in the Merced River. The mean SL of age-1 clams in the Merced River was larger than the mean SL of age-1 clams in the San Joaquin River, but the difference was not statistically significant.

Mean SL of age-2 clams was also significantly different among rivers (ANOVA: $F_{2,7}=$ $5.6, P<0.05$ ). Pairwise tests showed that mean SL of age-2 clams was larger in the Merced River than in the San Joaquin River, but was not different from mean SL of age-2 clams in the Tuolumne River. The mean SL of age-2 clams in the Tuolumne River was larger than the mean SL of age-2 clams in the San Joaquin River, but the difference was not statistically significant.

\section{Discussion}

Our study is the only one we are aware of that explores the ecology of $C$. fluminea in the small to medium-sized rivers of the southwestern United States. The published literature on introduced riverine populations of $C$. fluminea focuses largely on estuaries (e.g., Cohen et al. 1984, Boltovsky et al. 1997, Lucas et al. 2002, Morgan et al. 2003) and low-gradient sand-bottomed rivers (e.g., Leff et al. 1990; Blalock and Herod 1999). Also, relatively few studies have incorporated longitudinal sampling along a river (e.g., Leff et al. 1990, Mouthon 2003). Overall, densities of $C$. fluminea in the San Joaquin River watershed were similar to densities in studies conducted elsewhere that, like ours, did not consider smaller clams $(<3-5$ mm SL, Payne et al. 1989, Stites et al. 1995, Blalock and Herod 1999). However, in our study there were obvious differences in the distribution and abundance of C. fluminea both among and within rivers.

The most obvious difference among rivers was the low density and biomass of $C$. fluminea in the San Joaquin River relative to the 2 tributaries. Larger clams have been collected in the San Joaquin River, as reported in studies of contaminants (Leland and Scudder 1990, Brown 1997b), but they were rare and difficult to collect even from favored microhabitats. We documented the presence of larger clams, but they were very low in number (Fig. 3). There were also differences between the tributaries, with abundance and biomass peaking in the midreaches of the Tuolumne River but staying relatively consistent throughout the Merced River. The limited capability of our equipment to sample deeper water in the Merced River may have been a factor in the observed difference between tributaries; however, the difference in pattern remained when we considered only the sites where all transects were sampled (MR1, MR2, and MR4).

Flooding can affect the demographics of $C$. fluminea populations by transporting individuals out of the system and recolonizing the system with small individuals from upstream refugia (Payne et al. 1989, McMahon 1999); however, the lower San Joaquin River and tributaries have not suffered a major flood since early 1997, and flows were low to moderate in the 3 years preceding sampling. It seems unlikely that the tributary populations would recover rapidly from the 1997 flood but that the San Joaquin River would fail to recover after 7 years. Therefore, we do not believe flooding and transport of C. fluminea is a sufficient explanation for the observed lack of multiple year-classes in the San Joaquin River. 
Physical conditions within the 3 rivers were well within the known tolerances of $C$. fluminea. Specific conductivity was higher in the San Joaquin River than in the tributaries, but salinity (as indicated by specific conductance) was well below the $14 \mathrm{psu}$ (specific conductance of about $23,000 \mathrm{mS} \cdot \mathrm{cm}^{-1}$ ) threshold for adults and the 2 psu (specific conductance of about $3800 \mathrm{mS}$ - $\mathrm{cm}^{-1}$ ) threshold for larvae reported by McMahon (1999) at all sites. Values for $\mathrm{pH}$ were always above the lower limit of 5.6. In addition, concentrations of dissolved calcium were always above the concentration of $\sim 2.0$ $\mathrm{mg} \cdot \mathrm{L}^{-1}$, which is known to limit some other species of freshwater bivalves (Thorp and Covich 1991). Temperatures were also well below the $36^{\circ} \mathrm{C}$ lethal limit of C. fluminea (McMahon 1999). Thus, differences in temperature, salinity, $\mathrm{pH}$ or dissolved calcium are unlikely to explain the differences in density and biomass between the San Joaquin River and the tributaries. Clams were also present at sites with a variety of substrate types, indicating that appropriate substrate was not limiting. The low density and low biomass of $C$. fluminea in the San Joaquin River, despite apparently suitable environmental conditions and lack of significant correlations of density and biomass with environmental variables in the tributaries, suggest that the factors structuring the C. fluminea populations are not straightforward.

The calculated AFDM for a 10-mm SL clam was highest in the San Joaquin River, indicating that individual C. fluminea were in good physiological condition at the time we sampled. This is consistent with the positive correlations with chl- $a$ and results of studies from other geographic areas, which indicated that maximum condition occurs at locations with the highest food availability (reviewed by McMahon 1999). Foe and Knight (1985) reported that $C$. fluminea becomes food limited at chl- $a$ concentrations $<20 \mu \mathrm{g} \cdot \mathrm{L}^{-1}$ in the Sacramento River-San Joaquin River Delta. Concentrations of chl- $a$ in excess of this limit are typical of the lower San Joaquin River from June through September (Table 2; Leland 2003, Kratzer et al. 2004). The other sites did not exceed this threshold during our study (Tables 1, 2). However, density and biomass, which likely better reflect conditions for $C$. fluminea populations over longer time periods, were lowest on the San Joaquin River. In addition, San Joaquin
River C. fluminea shell length was smaller than tributary C. fluminea shell length for clams of the same age, and age-class structure was simpler in the San Joaquin River than in the tributaries. Thus, some factor other than food availability is likely contributing to the conflicting pattern of smallest-sized individuals and highest-condition individuals on the San Joaquin River.

In the absence of other factors, we would expect $C$. fluminea to invade the San Joaquin River and utilize the available food resources until abundances reached levels capable of filtering out most primary production, as has been reported elsewhere (Cohen et al. 1984, Lauritsen 1986, McMahon and Williams 1986). We hypothesize that water quality is responsible for the low clam biomass and small-sized individuals in the San Joaquin River. Because clam condition as measured by AFDM was higher for C. fluminea in the San Joaquin River during our June collection, despite the smaller sizes in an age class, we suggest that the water quality conditions responsible for the stress occur at other times of the year when temperature and water quality stresses are greater.

Corbicula fluminea is exposed to dissolved pesticides in all 3 rivers; however, individuals in the Tuolumne and Merced rivers are exposed to lower concentrations than those in the mainstem and west-side tributaries of the San Joaquin River (Brown 1997b, Domagalski et al. 1997, Domagalski and Munday 2003, Zamora et al. 2003, Brown et al. 2004). These pesticides can reach concentrations toxic to some invertebrates (Kuivila and Foe 1995). Clams from the mainstem and west-side tributaries of the San Joaquin River can also have high concentrations of organochlorine compounds in their tissues (Pereira et al. 1996, Brown 1997b). Boltovsky et al. (1997) observed that C. fluminea populations in a polluted area of the Paraná River, Argentina, had only low densities of older clams that produced larvae with very poor survival. A subsequent study confirmed the role of pollutants in limiting survival of juvenile C. fluminea (Cataldo et al. 2001). Mouthon (2003) hypothesized that concentrations of toxic contaminants lethal to pediveligers might explain low recruitment of C. fluminea in parts of the Saône and Rhône Rivers, France.

In addition to stress from toxic chemicals, clam populations in the San Joaquin River may experience sublethal physical stress. In 
particular, water temperatures can approach $30^{\circ} \mathrm{C}$ (Table 1) in midsummer and through the fall in this temperate climate. This condition is known to increase oxygen consumption (McMahon 1979), decrease filtration rate (Mattice 1979), and decrease metabolic rate (Ortman and Grieshaber 2003) of C. fluminea. It seems likely that cumulative and possibly synergistic environmental stresses may make the mainstem San Joaquin River a relatively inhospitable habitat for C. fluminea during the midsummer to fall period after our late-spring / early summer sampling period.

Conditions in the San Joaquin River need not be lethal to cause reduced abundances of clams. The juvenile and small C. fluminea that we did find in this river likely originated as larvae from both a small population of resident adult clams and from the large populations of mature clams in the tributaries. Thus, despite the environmental stresses, the San Joaquin River potentially receives a steady input of juvenile $C$. fluminea from other less-stressed systems. Larvae may have settled within the river and subsequently died, or they may simply have drifted through the mainstem San Joaquin River to the delta if conditions were stressful and if conditions inhibited settlement. Larger, previously settled C. fluminea are able to facilitate downstream drift to escape stressful conditions by extruding mucous drag lines into water currents (Prezant and Chalermwat 1984).

Emigration or mortality in response to environmental stress does not seem a likely explanation for the different patterns of distribution in the Merced and Tuolumne rivers. Data for the Merced and Tuolumne rivers suggest that environmental conditions were well within the tolerances of $C$. fluminea throughout both rivers for 2 years preceding the study. Recruitment of juveniles was not likely to be limiting on either river, as we found individuals of reproductive size $(6-10 \mathrm{~mm} \mathrm{SL})$ at the farthest upstream locations in all systems. In addition, observations on the Stanislaus River to the north (Fig. 1; Brian Quelvog, California Department of Fish and Game, written communication) and the Kern River to the south (California Academy of Sciences collection record CAS IZ 78077) indicate that there are likely populations in upstream reservoirs that can serve as sources of additional recruits to the river reaches in our study.

It seems likely that downstream transport and hydraulics play a role in the distribution of clams in the tributaries. High densities and high biomass of clams occur at the stations MR3 and TR3, representing the transition from rifflepool habitat with coarse substrate to run habitat with fine substrate. This pattern would be expected if clams behaved like substrate particles and were transported as a component of bed load. Clams would be moved downstream by high winter and spring flows and settle in the transition and low-gradient reaches that favor accumulation of sand and gravel. Downstream transport of clams has been identified as an important process in other systems (Eng 1979, Payne et al. 1989, Mouthon 2003). The lack of clam activity at low temperatures (Ortmann and Grieshaber 2003) would favor this hydraulics-dominated transport in winter and spring, when flow is dominated by snow melt runoff. Active migration (Prezant and Chalermwat 1984) may also occur in response to environmental conditions (Williams and McMahon 1989) at other times of the year when the clams are more active. The broad size ranges of $C$. fluminea in the areas of lower velocity and smaller substrate downstream of the transition zone and at TR4 are presumably due to local hydrodynamic conditions. The density and biomass of $C$. fluminea downstream of the habitat transition point differ substantially between the 2 tributaries, and the differences are likely the result of a number of interacting factors including recruitment, food availability, habitat conditions, and water quality.

Corbicula fluminea populations, similar to populations of other filter-feeding bivalves in culture (Dame 1996) and other invasive species in the wild (Thompson 2005), are likely to expand until food or physical conditions limit population growth. Physical conditions in the tributaries are unlikely to limit $C$. fluminea population growth except in the lowest reaches during summer periods when temperatures may seasonally stress populations $\left(>30^{\circ} \mathrm{C}\right)$. However, even these high temperatures are unlikely to kill healthy animals, which can survive at $36^{\circ} \mathrm{C}$ (McMahon 1999). The low chl- $a$ concentrations $\left(<<20 \mu \mathrm{g} \cdot \mathrm{L}^{-1}\right)$ and high biomasses suggest that filter-feeding clams are limited by 
food throughout the lower Merced and Tuolumne rivers. Thus, the reasons for differences in longitudinal patterns of population density, biomass, and age-class structure between tributaries are difficult to assess without understanding the dynamics of primary production over daily, seasonal, and annual time scales and without understanding the availability of alternative foods. Corbicula fluminea may filter bacteria and fine-particulate organic matter out of the water column to supplement the limited suspended algae food source. It seems more likely that clams are supplementing their energy intake through pedal feeding, as has been noted in other systems (Hakenkamp and Palmer 1999). Pedal feeding most likely occurs in the lower reaches of the rivers, where the velocities decrease, where the sediment is finer, and where the fine organic particles accumulate.

Corbicula fluminea is an important species in the delta ecosystem because of its ability to deplete phytoplankton resources (Lucas et al. 2002, Lopez et al. 2006). The low density and biomass of $C$. fluminea that we found in the San Joaquin River upstream of the delta suggests that the species is unlikely to have a large effect on the ecosystem of the mainstem San Joaquin River. In contrast, our biomass results for the tributaries are in the same range as for sites in the delta where C. fluminea can deplete phytoplankton, suggesting that C. fluminea may be an important species in the trophic dynamics of the tributaries to the San Joaquin River. Preliminary calculations of $C$. fluminea grazing rates at the 3 downstream sites in the Merced and Tuolumne rivers indicate that the clam populations are generally capable of consuming all phytoplankton primary production occurring in the lower reaches of the rivers; similar calculations in the mainstem San Joaquin River indicate that grazing there is significantly slower than production (L. Lucas personal communication). Additional studies will be needed to determine the role of C. fluminea in the tributary ecosystems. As C. fluminea continues to expand its range through South America and Europe (McMahon 1999), questions regarding its effects on organic carbon dynamics and trophic linkages are likely to become important in a wide array of environmental circumstances. Additional studies in the rivers of the arid southwestern United States could make important contributions to answering those questions.

\section{ACKNOWLEDGMENTS}

We thank Randy Dahlgren for providing the water quality data. We thank the reviewers for many useful comments that helped us to significantly improve the manuscript. Funding was provided by the Interagency Ecological Program and the National Research Program of the U.S. Geological Survey.

\section{Literature Cited}

Beaver, J.R., T.L. Crisman, and R.J. Brock. 1991. Grazing effects of an exotic bivalve (Corbicula fluminea) on hypereutrophic lake water. Lake and Reservoir Management 7:45-51.

Blalock, H.N., and J.J. Herod. 1999. A comparative study of stream habitat and substrate utilized by Corbicula fluminea in the New River, Florida. Florida Scientist 62:145-151.

Boltovsky, D., N. Correa, D. Cataldo, J. Stripeikis, AND M. Tudino. 1997. Environmental stress on Corbicula fluminea (Bivalvia) in the Paraná River Delta (Argentina): complex pollution-related disruption of population structures. Archiv für Hydrobiologie 138: 483-507.

Brown, L.R. 1997a. Water-quality assessment of the San Joaquin-Tulare basins, California: analysis of available information on aquatic biology, through 1992. U.S. Geological Survey, Water Supply Paper 2471, Washington, DC.

. 1997b. Concentrations of chlorinated organic compounds in biota and bed sediment in streams of the San Joaquin Valley, California. Archives of Environmental Contamination and Toxicology 33:357-368.

Brown, L.R., S.Y. Panshin, C.R. Kratzer, C. Zamora, AND J.M. GRONBERG. 2004. Occurrence, distribution, instantaneous loads, and yields of dissolved pesticides in the San Joaquin River Basin, California, during summer conditions, 1994 and 2001. U.S. Geological Survey, Scientific Investigations Report 2004-5083, Sacramento, CA.

Cataldo, D., J.C. Colombo, D. Boltovsky, C. Bilos, and P. LANDON. 2001. Environmental toxicity in the Paraná River Delta (Argentina): simultaneous evaluation of selected pollutants and mortality rates of Corbicula fluminea (Bivalvia) early juveniles. Environmental Pollution 112:379-389.

Cohen, R.R.H., P.V. Dresler, E.J.P. Phillips, and R.L. Cory. 1984. The effect of Asiatic clam, Corbicula fluminea, on phytoplankton of the Potomac River, Maryland. Limnology and Oceanography 29:170-180.

CRISP, D.J. 1971. Energy flow measurements. Pages 197279 in N.A. Holme and A.D. McIntyre, editors, Methods for the study of marine benthos. Blackwell Scientific Publications, London.

Dame, R.F. 1996. Ecology of marine bivalves: an ecosystem approach. CRC Press, Boca Raton, FL. 254 pp.

Domagalski, J.L., N.M. Dubrovsky, and C.R. Kratzer. 1997. Pesticides in the San Joaquin River, California: 
inputs from dormant sprayed orchards. Journal of Environmental Quality 26:454-465.

Domagalski, J.L., AND C. Munday. 2003. Evaluation of diazinon and chlorpyrifos concentrations and loads, and other pesticide concentrations, at selected sites in the San Joaquin Valley, California, April to August, 2001. U.S. Geological Survey, Water Resources Investigations Report 03-4088, Sacramento, CA.

ENG, L.L. 1979. Population dynamics of the asiatic clam, Corbicula fluminea (Muller), in the concrete-lined Delta-Mendota canal of central California. Pages 39-168 in J.C. Britton, editor, Proceedings, First International Corbicula Symposium. Texas Christian University, Research Foundation, Forth Worth.

FitzPatrick, F.A., I.R. Waite, P.J. D’Arconte, M.R. Meador, M.A. Maupin, and M.E. Gurtz. 1998. Revised methods for characterizing stream habitat in the National Water-Quality Assessment Program. U.S. Geological Survey, Water-Resources Investigations Report 98-4052, Sacramento, CA.

Foe, C., AND A. KNIGHT. 1985. The effect of phytoplankton and suspended sediment on the growth of Corbicula fluminea (Bivalvia). Hydrobiologia 127:105-115.

HAGER, S.W. 1994. Dissolved nutrient and suspended particulate matter data for the San Francisco Bay Estuary, California. October 1991-November 1993. U.S. Geological Survey Open-File Report 94-471.

Hakenkamp, C.C., and M.A. Palmer. 1999. Introduced bivalves in freshwater ecosystems: the impact of Corbicula on organic matter dynamics in a sandy stream. Oecologia 119:445-451.

HakenKamp, C.C., S.G. Ribblet, M.A. Palmer, C.W. Swan, J.W. REID, AND M.R. GoOdison. 2001. The impact of an introduced bivalve (Corbicula fluminea) on the benthos of a sandy stream. Freshwater Biology 46: 491- 501 .

INGRAM, W.M. 1959. Asiatic clams as potential pests in California water supplies. Journal of the American Water Works Association 51:363-370.

Kahrl, W.L., W.A. Bowen, S. Brand, M.L. Shelton, D.L. FulLER, AND D.A. RYAN. 1978. The California water atlas. The Governor's Office of Planning and Research, Sacramento, CA.

Kimmerer, W.J. 2002. Effects of freshwater flow on abundance of estuarine organisms: physical effects or trophic linkages. Marine Ecology Progress Series 243: $39-55$.

Kratzer, C.R., P.D. Dileanis, C. Zamora, S.R. Silva, C. Kendall, B.A. Bergamaschi, and R.A. Dahlgren. 2004. Sources and transport of nutrients, organic carbon, and chlorophyll- $a$ in the San Joaquin River upstream of Vernalis, California, during summer and fall, 2000 and 2001. U.S. Geological Survey, WaterResources Investigations Report 03-4127, Sacramento, CA.

Kratzer, C.R., And J.L. Shelton. 1999. Water quality assessment of the San Joaquin-Tulare Basins, California: analysis of available data on nutrients and suspended sediment in surface water, 1972-1990. U.S. Geological Survey Professional Paper 1587, Sacramento, CA. 118 pp.

Kuivila, K.M., AND C.G. Foe. 1995. Concentrations, transport, and biological effects of dormant spray pesticides in the San Francisco Estuary, California. Environmental Toxicology and Chemistry 14:11411150 .
Lauritsen, D.D. 1986. Filter-feeding in Corbicula fluminea and its effect on seston removal. Journal of the North American Benthological Society 5:165-172.

Lauritsen, D.D. and S. MozLEy. 1989. Nutrient excretion in the Asiatic clam, Corbicula fluminea. Journal of the North American Benthological Society 8:134-139.

LEFF, L.G., J.L. BurCh, AND J.V. McArthur. 1990. Spatial distribution, seston removal, and potential competitive interactions of the bivalves Corbicula fluminea and Elliptio complanata, in a coastal plain stream. Freshwater Biology 24:409-416.

LELAND, H.V. 2003. The influence of water depth and flow regime on phytoplankton biomass and community structure in a shallow, lowland river. Hydrobiologia 506-509:247-255.

Leland, H.V., ANd B.C. Scudder. 1990. Trace elements in Corbicula fluminea from the San Joaquin River California. Science of the Total Environment 97/98: 641-672.

Lopez, C.B., J.E. Cloern, T.S. Schraga, A.J. Little, L.V. LuCAS, J.K. Thompson, and J.R. Burau. 2006. Ecological values of shallow-water habitats: implications for the restoration of disturbed ecosystems. Ecosystems 9:422-440.

Lucas, L.V., J.E. Cloern, J.K. Thompson, and N.E. MonSEN. 2002. Functional variability of habitats within the Sacramento-San Joaquin Delta: restoration implications. Ecological Applications 12:1528-1547.

MacDonald, P.D.M., and P.E.J. Green. 1988. User's guide to Program MIX: an interactive program for fitting mixtures of distributions. Release 2.3, January 1988. Ichthus Data Systems, Hamilton, Ontario, Canada.

MatTICE, J.S. 1979. Interactions of Corbicula sp. with power plants. Pages 119-138 in J.C. Britton, editor, Proceedings, First International Corbicula Symposium. Texas Christian University Research Foundation, Forth Worth.

McMahon, R.F. 1979. Response to temperature and hypoxia in the oxygen consumption of the introduced freshwater clam Corbicula fluminea (Müller). Comparative Biochemistry and Physiology 63A:383388.

1983. Ecology of the invasive pest bivalve Corbicula. Pages 505-561 in W.D. Russell-Hunter, editor, The Mollusca. Volume 6, Ecology. Academic Press, Orlando, FL.

1999. Invasive characteristics of the freshwater bivalve, Corbicula fluminea. Pages 315-346 in R. Claudi and J.H. Leach, editors, Nonindigenous freshwater organisms: vectors, biology, and impacts. Lewis Publishers, Boca Raton, FL.

McMahon, R.F., and C.J. Williams. 1986. A reassessment of growth rate, life span, life cycles and population dynamics in a natural population and field caged individuals of Corbicula fluminea (Müller) (Bivalvia: Corbiculacea). American Malacological Bulletin, Special Edition 2:151-166.

Morgan, D.E., M. Keser, J.T. Swenarton, and J.F. Foertch. 2003. Population dynamics of the Asiatic clam, Corbicula fluminea (Müller) in the lower Connecticut River: establishing a foothold in New England. Journal of Shellfish Research 22:193-203.

MounT, J.F. 1995. California rivers and streams. University of California Press, Berkeley. 359 pp.

Mouthon, J. 2003. Longitudinal and temporal variations of density and size structure of Corbicula fluminea 
(Bivalvia) populations in the Saône and Rhône Rivers (France). Annales de Limnologie 39:15-25.

Ortmann, C., AND M.K. Grieshaber. 2003. Energy metabolism and valve closure behavior in the Asian clam Corbicula fluminea. Journal of Experimental Biology 206:4167-4178.

Parsons, T.R., Y. Maita, and C.M. LaLLi. 1984. A manual of chemical and biological methods for seawater analysis. Pergamon Press, Oxford, U.K. 173 pp.

Payne, B.S., A.C. Miller, P.D. Hartfield, and R.F. MCMAHON. 1989. Variation in size demography of lotic populations of Corbicula fluminea (Müller). Nautilus 103:78-82.

Pereira, W.E., J.L. Domagalski, F.D. Hostettler, L.R. BROWN, AND J.B. RaPP. 1996. Occurrence and accumulation of pesticides and organic contaminants in river sediment, water, and clam tissues from the San Joaquin River and tributaries, California. Environmental Toxicology and Chemistry 15:172-180.

Phelps, H.L. 1994. The Asiatic clam (Corbicula fluminea) invasion and system-level ecological change in the Potomac River Estuary near Washington, D.C. Estuaries 17:614-621.

Prezant, R.S., and K. Chalermwat. 1984. Flotation of the bivalve Corbicula fluminea as a means of dispersal. Science 225:1491-1493.

Stites, D.L., A.C. Benke, and D.M. Gillespie. 1995 Population dynamics, growth, and production of the Asiatic clam, Corbicula fluminea, in a blackwater river Canadian Journal of Fisheries and Aquatic Sciences $52: 425-437$.
Thompson, J.K. 2005. One estuary, one invasion, two responses: phytoplankton and benthic community dynamics determine the effect of an estuarine invasive suspension feeder. Pages 291-316 in S. Olenin and R. Dame, editors, The comparative roles of suspension feeders in ecosystems. Kluwer Publishing, Dordrecht, The Netherlands.

Thorpe, J.H., AND A.P. Covich. 1991. Ecology and classification of North American freshwater invertebrates. Academic Press, Inc., San Diego, CA.

[USGS] United States Geological Survey. 2005. Nonindigenous aquatic species [cited 12 December 2005]. Available from: http://nas.er.usgs.gov/.

WiLLIAMS, C.J., AND R.F. McMaHON. 1989. Annual variation of tissue biomass and carbon and nitrogen content in the freshwater bivalve Corbicula fluminea relative to downstream dispersal. Canadian Journal of Zoology 67:82-90.

Zamora, C., C.R. Kratzer, M.S. Majewski, and D.L. KNIFONG. 2003. Diazinon and chlorpyrifos loads in precipitation and urban and agricultural storm runoff during January and February 2001 in the San Joaquin River Basin, California. U.S. Geological Survey, Water Resources Investigations Report 03-4091, Sacramento, CA.

Received 8 August 2006 Accepted 13 June 2007 